\title{
The Complement System: A Powerful Modulator and Effector of Astrocyte Function in the Healthy and Diseased Central Nervous System
}

\author{
Marcela Pekna $1,3,4, * \mathbb{D}$ and Milos Pekny $2,3,4$ \\ 1 Laboratory of Regenerative Neuroimmunology, Center for Brain Repair, Department of Clinical Neuroscience, \\ Institute of Neuroscience and Physiology, Sahlgrenska Academy at the University of Gothenburg, \\ 40530 Gothenburg, Sweden \\ 2 Laboratory of Astrocyte Biology and CNS Regeneration, Center for Brain Repair, Department of Clinical \\ Neuroscience, Institute of Neuroscience and Physiology, Sahlgrenska Academy at the University of \\ Gothenburg, 40530 Gothenburg, Sweden; milos.pekny@neuro.gu.se \\ 3 Florey Institute of Neuroscience and Mental Health, Parkville, Melbourne 3010, Australia \\ 4 School of Medicine and Public Health, University of Newcastle, Newcastle 2308, Australia \\ * Correspondence: marcela.pekna@neuro.gu.se; Tel.: +46-31-786-3581
}

Citation: Pekna, M.; Pekny, M. The Complement System: A Powerful

Modulator and Effector of Astrocyte Function in the Healthy and Diseased Central Nervous System. Cells 2021, 10, 1812. https://doi.org/10.3390/ cells10071812

Academic Editors: Pavel Hozák, Elly Hol and Roy Andrew Quinlan

Received: 15 June 2021

Accepted: 14 July 2021

Published: 17 July 2021

Publisher's Note: MDPI stays neutral with regard to jurisdictional claims in published maps and institutional affiliations.

Copyright: (C) 2021 by the authors. Licensee MDPI, Basel, Switzerland. This article is an open access article distributed under the terms and conditions of the Creative Commons Attribution (CC BY) license (https:// creativecommons.org/licenses/by/ $4.0 /)$.

\begin{abstract}
The complement system, an effector arm of the innate immune system that plays a critical role in tissue inflammation, the elimination of pathogens and the clearance of dead cells and cell debris, has emerged as a regulator of many processes in the central nervous system, including neural cell genesis and migration, control of synapse number and function, and modulation of glial cell responses. Complement dysfunction has also been put forward as a major contributor to neurological disease. Astrocytes are neuroectoderm-derived glial cells that maintain water and ionic homeostasis, and control cerebral blood flow and multiple aspects of neuronal functioning. By virtue of their expression of soluble as well as membrane-bound complement proteins and receptors, astrocytes are able to both send and receive complement-related signals. Here we review the current understanding of the multiple functions of the complement system in the central nervous system as they pertain to the modulation of astrocyte activity, and how astrocytes use the complement system to affect their environment in the healthy brain and in the context of neurological disease.
\end{abstract}

Keywords: astrocytes; the complement system; C3; reactive astrocytes; reactive gliosis; neurodegeneration; neural plasticity

\section{Introduction}

By virtue of its ability to sense and rapidly respond to diverse danger signals, the complement system plays an essential role in the innate immune responses and constitutes the first line of defense against pathogens such as bacteria, viruses, mycoplasma, fungi, and protozoa. Whereas the functions of the complement system in the elimination of pathogens, antigen-antibody complexes, dead cells and tissue debris, and their involvement in the regulation of the responses mediated by antibodies and cells of the adaptive immune system have been well recognized for many decades, the homeostatic and non-immune tasks of the complement proteins only recently began to be unraveled. Liver cells are the main source of complement proteins in the blood, but complement proteins are also produced locally in many tissues including the central nervous system (CNS). There is an exponentially growing amount of evidence for the role of the complement system in the CNS development [1-8], maintenance and restoration of CNS homeostasis [9,10], and in the regulation of neural plasticity [11-14]. However, the complement system is also an important driver of age-related synapse loss and cognitive decline [15] and plays a principal role in the neurodegeneration processes [16-22]. Astrocytes are a major source of the complement system proteins, particularly of the third complement component (C3), 
and they stand out as a very prominent player or effector in many of the complementmediated processes. Through a number of complement receptors expressed on their cell membrane, astrocytes are also well equipped to sense the level of complement activation in their vicinity, as well as receive and respond to complement-derived signals sent by other cells.

\section{The Complement System}

The complement system consists of more than 50 secreted and cell membrane-bound proteins that exert their functions through highly ordered interactions. Liver cells are the main source of complement proteins in the blood. Complement proteins are also produced locally in many tissues including the CNS. The very powerful and potentially deleterious effector functions of the complement system place high demands on its control. The strict control of the complement system is achieved at two levels: activation of inactive precursors and inactivation of the active components through degradation. Many of the secreted complement proteins are produced as inactive precursors and need to be activated through conformational changes induced, for example, by binding to the right target, such as the pathogen-associated molecular patterns or antigen-antibody complex, or through proteolytic cleavage. The complement system also includes a number of fluid-phase and membrane-bound regulatory proteins that protect healthy host cells and ensure that the activation and effector functions of the active proteins and their fragments are limited both in space and in time.

\subsection{Activation of the Complement System}

There are three canonical pathways through which the complement system can be activated: the classical pathway, the alternative pathway, and the lectin pathway. The prototypic trigger of the classical pathway is the binding of the $\mathrm{C} 1$ complex to the $\mathrm{Fc}$ moieties of antigen-bound IgG or IgM. The $\mathrm{C} 1$ complex consists of $\mathrm{C} 1 \mathrm{q}$, which serves the role of a pattern recognition molecule, associated with a tetramer of two each of the serine proteases $\mathrm{C} 1 \mathrm{r}$ and $\mathrm{C} 1 \mathrm{~s}$. Other ligands for the complement component $\mathrm{C} 1 \mathrm{q}$ include molecular patterns on certain pathogens (such as Gram-positive and Gram-negative bacteria and some viruses), the C-reactive protein-phosphocholine complex, pentraxin-3, serum amyloid P component, beta-amyloid fibrils, DNA, mitochondrial membranes, as well as different targets on apoptotic cells such as phosphoserine, histones and annexins (reviewed by e.g., [23,24]). Binding of $\mathrm{C} 1 \mathrm{q}$ to a ligand induces autoactivation of $\mathrm{C} 1 \mathrm{r}$ followed by sequential proteolytic activation of $\mathrm{C} 1 \mathrm{~s}, \mathrm{C} 4$ and $\mathrm{C} 2$, which results in the formation of activator-bound $\mathrm{C} 3$ convertase (C4b2a) of the classical pathway, an enzymatic complex that cleaves $\mathrm{C} 3$ into $\mathrm{C} 3 \mathrm{a}$ and $\mathrm{C} 3 \mathrm{~b}$. C3a is released into the fluid-phase and binds to the $\mathrm{C} 3 \mathrm{a}$ receptor $(\mathrm{C} 3 \mathrm{aR})$ or is rapidly inactivated by carboxypeptidases that remove its $\mathrm{C}$-terminal arginine residue. $\mathrm{C} 3 \mathrm{~b}$ becomes covalently bound to the activator via exposed internal thioester bond, thus irreversibly tagging and opsonizing the activator for recognition by cells expressing complement receptors (CR) 1-4 and CRIg, Figure 1.

The pattern recognition molecules of the lectin pathway are the collectins mannanbinding lectin and collectin-LK and ficolins $\mathrm{H}, \mathrm{M}$, and $\mathrm{L}$, which recognize the sugar moieties and acetyl groups of glycoproteins and glycolipids on bacteria, viruses, fungi, and protozoa, but also host organelles, mitochondria and natural IgM bound to neo-epitopes exposed on apoptotic and necrotic host cells. Similar to the C1 complex of the classical pathway, binding of collectins or ficolins to an activator leads to the autoactivation and proteolytic activation of the serine proteases they are associated with, namely mannan-binding lectinassociated serine protease 1 and 2, followed by activation of C2 and C4 and formation of activator-bound $\mathrm{C} 3$ convertase $\mathrm{C} 4 \mathrm{~b} 2 \mathrm{a}$. Activation of the classical and lectin pathways thus leads to the covalent binding of $\mathrm{C} 3 \mathrm{~b}$ to the activator surface, Figure 1. 


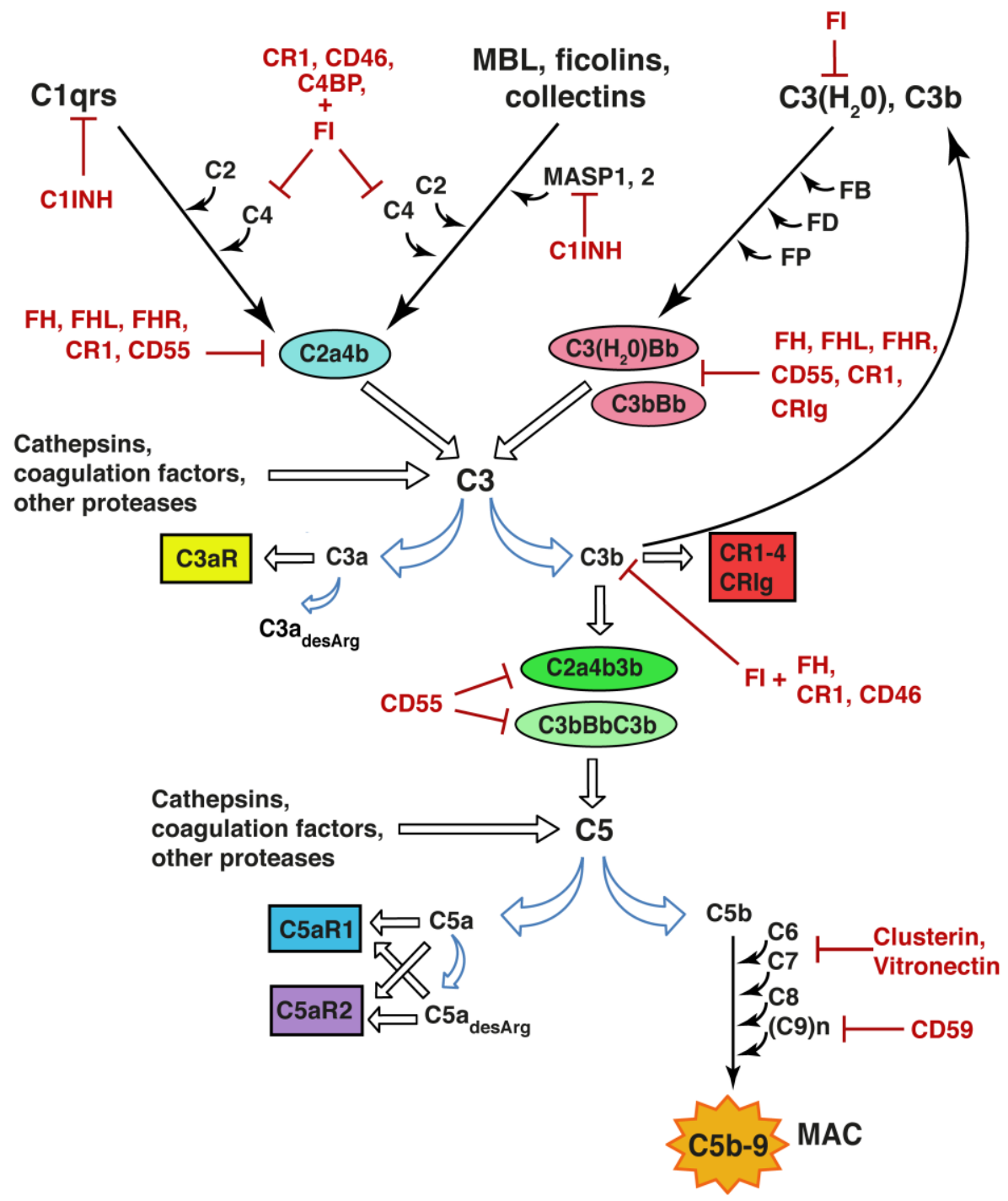

Figure 1. Complement system activation. Upon binding to a target structure, e.g., antigen-antibody complex or as yet unidentified synaptic component, $\mathrm{C} 1 \mathrm{q}$ triggers the activation of the classical pathway leading to formation of the $\mathrm{C} 2 \mathrm{a} 4 \mathrm{~b}$ convertase and the proteolytic activation of $\mathrm{C} 3$, opsonization of the target with $\mathrm{C} 3 \mathrm{~b}$, and release of $\mathrm{C} 3 \mathrm{a}$. Recognition of microbial sugar moieties by ficolins, collectins or mannan-binding lectin (MBL) in complex with mannan-binding lectin-associated serine protease 1 and 2 (MASP1, 2) initiates the lectin pathway. The alternative pathway is activated when spontaneous hydrolysis of the internal thioester bond in $\mathrm{C} 3$ leads to the conformational change of the C3 molecule resulting in $\mathrm{C} 3\left(\mathrm{H}_{2} \mathrm{O}\right)$ with the ability to bind factor $\mathrm{B}(\mathrm{FB})$. $\mathrm{C} 3\left(\mathrm{H}_{2} \mathrm{O}\right)$ or $\mathrm{C} 3 \mathrm{~b}$ bound FB is cleaved by factor $\mathrm{D}(\mathrm{FD})$ to generate the $\mathrm{C} 3\left(\mathrm{H}_{2} \mathrm{O}\right) \mathrm{Bb}$ and $\mathrm{C} 3 \mathrm{bBb}$ convertase, respectively. These enzymatic complexes are stabilized by properdin (FP). Through binding of $\mathrm{C} 3 \mathrm{~b}$, the $\mathrm{C} 3$ convertases acquire the ability to cleave $\mathrm{C} 5$ to form $\mathrm{C} 5 \mathrm{a}$ and $\mathrm{C} 5 \mathrm{~b}$. C 3 and $\mathrm{C} 5$ can also be cleaved by cathepsins, several coagulation factors, and other proteases. $\mathrm{C} 5 \mathrm{~b}$ recruits $\mathrm{C} 6, \mathrm{C} 7, \mathrm{C} 8$, and multiple $\mathrm{C} 9$ molecules to form C5b-9, also called membrane attack complex (MAC) on the target membrane. C3a and C5a exert their effects through the C3aR1, C5aR1 and C5aR2 receptors. Removal of the C-terminal arginine by carboxypeptidases generates $\mathrm{C} 3 \mathrm{a}_{\text {desArg }}$ and $\mathrm{C} 5 \mathrm{a}_{\text {desArg }}$. $\mathrm{C} 3 \mathrm{~b}$ and some of its degradation fragments can bind to complement receptors (CR) 1-4 and CRIg. At multiple levels, the activation of the complement activation is negatively regulated by inhibitory enzymes and their cofactors. C1INH: C1 inhibitor; C4BP: C4 binding protein; FH: factor H; FHL: factor H-like protein; FHR: factor $\mathrm{H}$-related protein; FI: factor I. 
The C3 convertase of the alternative pathway is formed through the recruitment of factor $\mathrm{B}$ to an activator-bound $\mathrm{C} 3 \mathrm{~b}$; factor $\mathrm{B}$ in complex with $\mathrm{C} 3 \mathrm{~b}$ is subsequently cleaved by factor $\mathrm{D}$, thus generating the $\mathrm{C} 3$ convertase $\mathrm{C} 3 \mathrm{bBb}$. The $\mathrm{C} 3 \mathrm{bBb}$ complex then generates multiple copies of $\mathrm{C} 3 \mathrm{~b}$ and serves as a very powerful amplifier of activation triggered by the classical and lectin pathways. In addition to its generation through the activator-bound $\mathrm{C} 4 \mathrm{~b} 2 \mathrm{a}$ and $\mathrm{C} 3 \mathrm{bBb}$ convertases, $\mathrm{C} 3 \mathrm{~b}$ can be produced by the fluid-phase $\mathrm{C} 3$ convertase $\mathrm{C} 3\left(\mathrm{H}_{2} \mathrm{O}\right) \mathrm{Bb}$. $\mathrm{C} 3\left(\mathrm{H}_{2} \mathrm{O}\right)$ is constitutively generated by a slow-rate hydrolysis of the internal thioester bond of $\mathrm{C} 3$, which leads to the conformational change of the $\mathrm{C} 3$ molecule, acquisition of $\mathrm{C} 3 \mathrm{~b}$ properties, and binding of factor $\mathrm{B}$. While the $\mathrm{C} 3\left(\mathrm{H}_{2} \mathrm{O}\right)$ activity is proteolytically inhibited by factor I, the half-life of the $\mathrm{C} 3$ convertases of the alternative pathway is increased by properdin, which acts as a $\mathrm{C} 3$ convertase-stabilizing factor, Figure 1.

Through the recruitment of $\mathrm{C} 3 \mathrm{~b}$, the activator-bound $\mathrm{C} 3$ convertases acquire the ability to cleave $\mathrm{C} 5$ into $\mathrm{C} 5 \mathrm{a}$ and $\mathrm{C} 5 \mathrm{~b}$, and thus initiate the terminal pathway of complement activation. While $\mathrm{C} 5 \mathrm{a}$ is released into the fluid-phase and exerts its actions through binding to cell membrane receptors $\mathrm{C} 5 \mathrm{aR} 1$ and $\mathrm{C} 5 \mathrm{aR} 2, \mathrm{C} 5 \mathrm{~b}$ binds to the activator surface and together with $\mathrm{C} 6, \mathrm{C} 7, \mathrm{C} 8$ and multiple $\mathrm{C} 9$ molecules becomes part of the membrane attack complex that forms a pore in the cell membrane and can lead to the lysis of the target cells or bacteria. In sublytic amounts, the membrane attack complex can modulate inflammation-associated functions of the host cell.

In addition to the convertases mentioned above, $\mathrm{C} 3$ and $\mathrm{C} 5$ can be proteolytically activated directly by mannan-binding lectin-associated serine protease 1 [25], non-complement proteases such as neutrophil elastase, cathepsins [26,27], granulocyte neutral proteases [28], lysosomal enzymes, kallikrein, as well as coagulation factors XIa, Xa, IXa, thrombin, and plasmin [29,30], Figure 1.

\subsection{Regulators of the Complement System}

As mentioned above, the constitutive mode of activation together with the huge amplification power of the alternative pathway pose potential danger to the host cells and thus demand strict spatiotemporal control of the active components, convertases, as well as the membrane attack complex. The protection of host cells from the bystander effect of $\mathrm{C} 3 \mathrm{~b}$ deposition is achieved by fluid-phase regulators such as factor $\mathrm{H}$, factor $\mathrm{H}$-like protein, complement factor H-related proteins 2 and 4, and C4-binding protein, which all facilitate the decay of the $\mathrm{C} 3$ convertases. In addition, factor I is a serine protease that degrades cofactor bound $\mathrm{C} 3 \mathrm{~b}$ and $\mathrm{C} 4 \mathrm{~b}, \mathrm{C} 1$-inhibitor inhibits serine proteases including those with complement-activating properties. Membrane-bound CR1 (CD35) and decay accelerating factor (CD55) facilitate the decay of the C3 convertases. CD46 and CR1 act as cofactors for factor I-mediated proteolytic degradation of $\mathrm{C} 4 \mathrm{~b}, \mathrm{C} 3 \mathrm{~b}$ and their fragments. The formation of membrane attack complex on host cells is inhibited by fluid-phase clusterin and vitronectin, and the membrane-bound CD59. The biological activity and potency of C3a and C5a is controlled through the removal of C-terminal arginine residue by carboxypeptidases generating $\mathrm{C} 3 \mathrm{a}_{\text {desArg }}$ and $\mathrm{C} 5 \mathrm{a}_{\text {desArg }}$, respectively, [24]), Figure 1.

\subsection{The Complement System Receptors}

The five currently known CRs all bind C3b and/or its degradation products iC3b and C3d. CR1 binds C3b, C4b, as well as iC3b and C3d. It serves to remove antigen-antibody complexes, promote phagocytosis, and to capture complement-opsonized antigens for $\mathrm{B}$ cell stimulation by antigen presenting cells, the latter a function shared with CR2 (CD21). The heterodimeric receptors CR3 (CB11b/CD18) and CR4 (CD11c/CD18) are phagocytic receptors that bind $\mathrm{iC} 3 \mathrm{~b}$. The fifth $\mathrm{CR}, \mathrm{CRIg}$, is involved in the clearance of $\mathrm{C} 3 \mathrm{~b}$ and $\mathrm{iC} 3 \mathrm{~b}$ tagged pathogens by the Kupffer cells in the liver. CRIg also inhibits the C3bBb convertase.

$\mathrm{C} 3 \mathrm{a}$ and $\mathrm{C} 5 \mathrm{a}$, the smaller fragments generated through the proteolytic activation of C3 and C5, respectively, exert their functions through their canonical G-protein coupled receptors $\mathrm{C} 3 \mathrm{aR}$ and $\mathrm{C} 5 \mathrm{aR} 1$. C3aR and C5aR1 are expressed on endothelial, smooth muscle 
and myeloid cells, and signaling through these receptors has long been known to increase vascular permeability, stimulate smooth muscle contraction, and leukocyte chemotaxis, as well as activate myeloid cells such as neutrophils, monocytes/macrophages, basophils, and platelets [31]. While $\mathrm{C} 3 \mathrm{a}_{\text {desArg }}$ no longer binds to $\mathrm{C} 3 \mathrm{aR}, \mathrm{C} 5 \mathrm{a}_{\text {desArg }}$ binds to $\mathrm{C} 5 \mathrm{aR} 1 \mathrm{but}$ does not activate receptor signaling. Both $\mathrm{C} 5 \mathrm{a}$ and $\mathrm{C} 5 \mathrm{a}_{\mathrm{desArg}}$ also bind to $\mathrm{C} 5 \mathrm{aR} 2$. Although unable to couple to G-proteins, $\mathrm{C} 5 \mathrm{aR} 2$ can function as a positive modulator for responses induced by C3aR and C5aR [32] as well as other signaling pathways [33].

\subsection{The Intracellular Complement System}

Many types of human cells, including T cells, B cells, monocytes, neutrophils, fibroblasts, and airway epithelial cells take up, store, and intracellularly activate $\mathrm{C} 3$ through a convertase-independent mechanism [26,34,35]. Intracellular complement, in particular C3, and $\mathrm{C} 3 \mathrm{a}$ and $\mathrm{C} 3 \mathrm{~b}$ generated from $\mathrm{C} 3$ by cathepsin $\mathrm{L}$, is essential for the development of $\mathrm{T}$ cell-mediated responses [26], promotes cell survival [34-36] and modulates intracellular metabolism [37]. Notably, even cells that are not able to produce $\mathrm{C} 3$ have been shown to internalize $\mathrm{C} 3$ in its hydrolytic form $\mathrm{C} 3\left(\mathrm{H}_{2} \mathrm{O}\right)$ and use it as the source of $\mathrm{C} 3 \mathrm{a}$, although the specific receptor involved in this process remains to be identified [38].

\section{Astrocytes, Astrocyte Activation and Reactive Gliosis}

Astrocytes are glial cell of neuroectodermal origin that have many functions in both healthy and diseased CNS [39-41]. Through thousands of fine cellular processes, astrocytes are in contact with neuronal synapses and form end-feet wrapping around blood capillaries, constituting a key component of the blood-brain barrier [40,42,43]. Astrocytes play a major role in the maintenance of the CNS homeostasis, control and support of neurons, neurotransmitter recycling, control of blood flow, and the induction, functional control, and removal of neuronal synapses [44-51]. Astrocytes are also an essential component of the glymphatic system, a brain-wide fluid transport pathway that supports the clearance of potentially harmful metabolic or protein waste products, such as amyloid- $\beta$, through the rapid and circadian rhythm-dependent exchange of cerebrospinal fluid and interstitial fluid along perivascular pathways [52,53].

Changes in CNS homeostasis, aging, as well as various kinds of pathological conditions, including acute and chronic injury and infection, trigger a broad range of general and context-specific astrocyte responses [54-56]. These responses span from astrocyte activation, induced by physiological signals and physiological alterations of CNS homeostasis, to disease and injury-associated astrocyte reactivity [41,55]. Reactive astrocytes are key components of reactive gliosis, which also includes reactive microglia [54,57-59]. Astrocyte reactivity is not an on-off response, but rather a continuum of multiple states $[39,56]$ with both general and disease-specific components, with astrocytes in the same tissue and disease condition exhibiting substantial heterogeneity $[60,61]$. The most severe form of reactive gliosis is the glial scar that seals the penetrating lesion from the surrounding healthy nervous tissue $[39,62]$. The functions of reactive astrocytes are disease-specific and often even disease stage-dependent, encompassing neuroprotection and adaptive plasticity-promoting properties on one end and neurotoxicity and malfunction on the other end of their phenotypic spectrum [41].

The JAK/STAT3 signaling pathway is an important switch controlling a number of molecular and functional changes in reactive astrocytes. Signaling molecules, such as transforming growth factor (TGF) $\alpha$, ciliary neurotrophic factor (CNTF), interleukin (IL)-6, leukemia inhibitory factor (LIF), or oncostatin $M$ have been shown to trigger astrocyte activation [63-68]. These signaling events lead to changes in gene expression, metabolism, cell morphology and cell proliferation $[39,69]$. Indeed, reactive astrocytes are characterized by hypertrophy of their cellular processes and exhibit changes in the expression of many genes including the up-regulation of glial fibrillary acidic protein (GFAP), the main component of astrocyte cytoplasmic intermediate filaments (also known as nanofilaments) [39,70,71]. Astrocyte cytoplasmic nanofilaments are composed of GFAP, vimentin, and in some cases 
also nestin and synemin [71-75]. Cytoplasmic nanofilaments are highly dynamic structures that are involved in cell signaling and cell migration, determine cellular viscoelastic properties, and act as a signaling platform regulating cell stress responses [39,73,76-79].

Many of the complement proteins, including the proteins involved in complement activation, complement receptors as well as regulators (CD46, CD55, CD59), are expressed by astrocytes. As the roles of complement in CNS responses to infection have been discussed elsewhere, we will focus on the novel, non-canonical and modulatory functions of the complement system with implications for astrocytes.

\section{The Complement System: A Modulator of Astrocyte Functions}

The reciprocal signaling between astrocytes and microglia, the resident immune cells of the CNS, appears to play a critical role in determining the reactive astrocyte phenotype. Astrocytes express C3aR [80-82], C5aR1 [83-85], C5aR2 [86], and CR3 [87], as well as Megf10, a phagocytic receptor that can also bind C1q [88]. gC1qR, a receptor for the globular domain of $\mathrm{C} 1 \mathrm{q}$, with a potential role in phagocytosis, and $\mathrm{cC} 1 \mathrm{qR} /$ calreticulin which binds the collagen domain of C1q [89], were reported to be expressed on human astrocytes [90] and on rat astrocytes [91], respectively. CD91/low-density lipoprotein receptor-related protein, is a multi-scavenger receptor that was shown to directly interact with C1q for clearance of C1q and C1q-bound material [92], and is expressed by multiple cell types including astrocytes [93]. CD93 is another C1q binding phagocytic receptor that is expressed by neural stem cells and neurons [94]. CD93 negatively regulates astrogenesis in the developing brain but does not seem to be expressed by mature astrocytes [94]. Human astrocytes were reported to also express CR1 and CR2 [95,96]. Given their broad expression of receptors for complement proteins and their activation products, it is therefore not surprising that the complement system has emerged as an important factor in the cross-talk between microglia and astrocytes, Figure 2 .

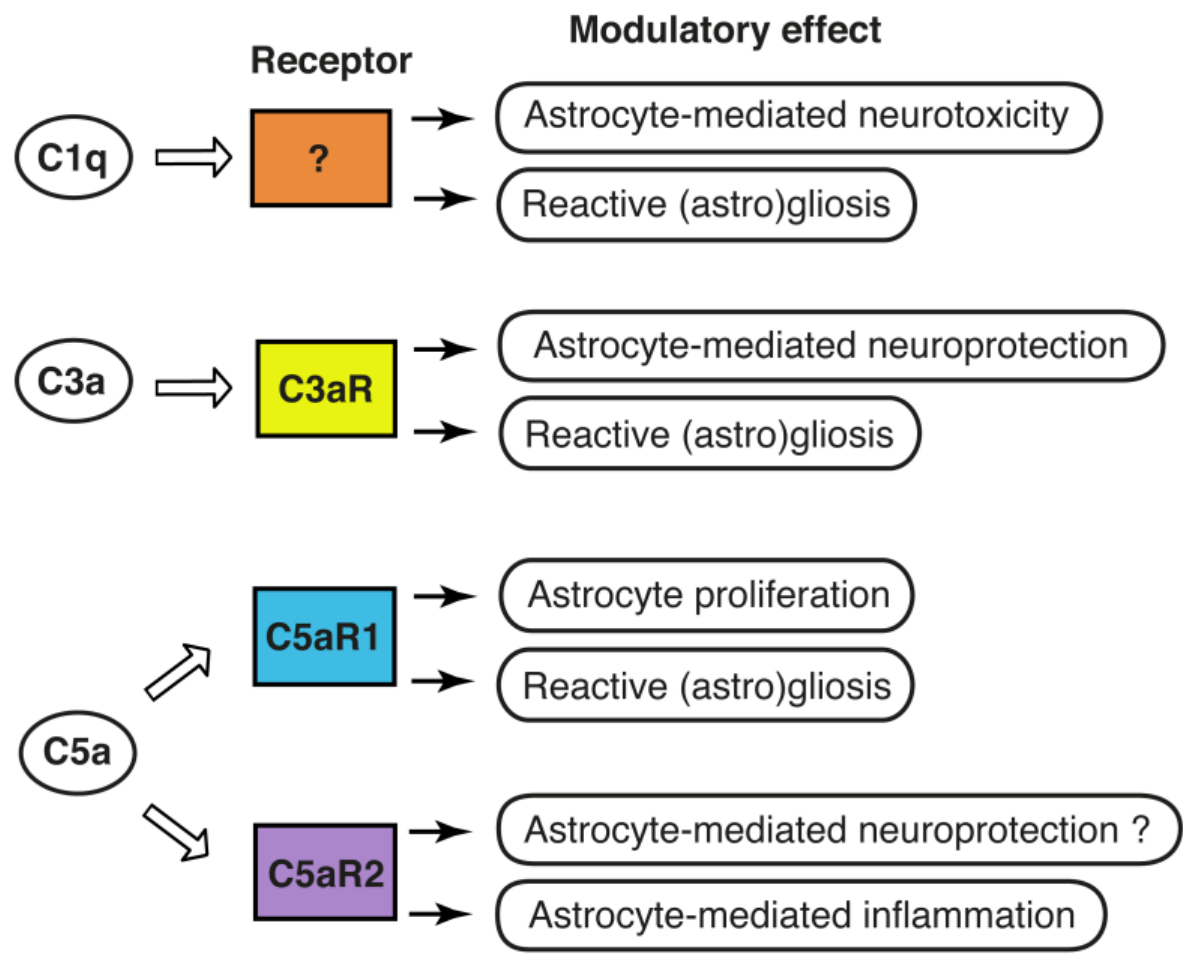

Figure 2. Complement is a modulator of astrocyte function: known and putative effects of the complement components C1q, C3 and C5 on astrocytes. While there are several potential candidates, the specific receptor through which $\mathrm{C} 1 \mathrm{q}$ exerts its modulatory effects on astrocytes is currently unknown. C3a and C5a exert their modulatory effects through C3aR, C5aR1 and C5aR2. 
Microglia-derived cytokines such as TNF $\alpha$, IL-1 $\beta$ and IL-6 were shown to transform astrocytes into neuroprotective phenotype [97], whereas C1q has been put forward as one of the signaling molecules needed for the induction of the so called neurotoxic astrocyte by microglia [98] and an Alzheimer's disease-specific modulator of the cellular cross-talk between microglia and astrocytes [99]. However, the astrocyte receptor needed for C1q to exhibit this effect is not known. One possible candidate is Megf10, which is predominantly expressed by astrocytes [87]. Astrocyte expression of Megf10 and CR3 is increased with age [100] as is the microglial expression of C1q [101]. Indeed, binding of C1q to Megf10 is required for normal clearance of apoptotic cells by astrocytes [88], and Megf10 is critical for neuronal activity-dependent synapse remodeling by astrocytes [102]. Other candidates worth investigating in this context include $\mathrm{cC1qR}, \mathrm{gC1qR}$ and CD91.

Using human pluripotent stem cell-derived tri-culture system containing neurons, astrocytes and microglia, a recent study demonstrated that, at least in the context of human Alzheimer's disease, C3 secreted by astrocytes is required for increased C3 release by microglia [99]. Further, this study showed that the ability of microglia to clear C1qcomplexes is impaired when microglia are cultured with C3-deficient compared to wildtype astrocytes [99]. These findings identified C3 as a critical factor in reciprocal signaling between microglia and astrocytes; however, the $\mathrm{C} 3$ or C3-derived fragment-binding entity on microglia is currently unknown. In light of its high expression by microglia, C3aR is clearly a candidate receptor to be investigated in this context. Indeed, cross-talk between astrocyte secreted C3 and microglial C3aR was shown to regulate phagocytosis of amyloid$\beta$ by cultured primary microglia [103].

Astrocytes express $\mathrm{C} 3 \mathrm{aR}$ [80-82] and respond to $\mathrm{C} 3 \mathrm{a}$ by changes in intracellular signaling [84]. In the unchallenged CNS, the source of C3a is conceivably C3 produced by the glial cells. In the acutely injured brain, C3-C3a can originate from astrocytes and microglia, as well as from the systemic circulation via leakage of C3 to the brain parenchyma through the dysfunctional blood-brain barrier. The exact mechanisms of complement activation and C3a generation in the naive and injured brain warrant further investigation. Insults such as brain ischemia increase astrocyte expression of C3aR [82,104,105], and there is experimental evidence for the neuroprotective effects of $\mathrm{C} 3 \mathrm{aR}$ signaling in astrocytes. Astrocytes respond to C3a by the expression of cytokines such as interleukin (IL)-6, IL8, and nerve growth factor (NGF) [83,106,107]. C3a promotes astrocyte survival after ischemic stress by inhibiting ERK signaling-mediated apoptotic pathway and caspase-3 cleavage [82]. C3a is neuroprotective against excitotoxicity, but only when neurons are co-cultured with astrocytes [108]. In vivo studies provide further support for the beneficial effects of $\mathrm{C} 3 \mathrm{a} / \mathrm{C} 3 \mathrm{aR}$ after brain injury and the involvement of astrocytes therein. Transgenic mice expressing C3a under the control of GFAP promoter, i.e., in astrocytes, were protected against brain tissue loss due to neonatal hypoxic-ischemic brain injury [109], a major cause of long-term neurological sequelae of birth complications such as intellectual disability, epilepsy, and cerebral palsy [110]. Memory impairment due to neonatal hypoxic-ischemic injury was mitigated by intraventricular administration of $\mathrm{C} 3 \mathrm{a}$ in wild-type mice but not in mice lacking C3aR [109]. Intranasal treatment with C3a reduced reactive gliosis in mice with neonatal hypoxic-ischemic injury and improved long-term cognitive function [111]. In the adult brain, signaling through neuronal $\mathrm{C} 3 \mathrm{aR}$ modulates dendritic morphology and the function of synapses [17], and stimulates neural plasticity after ischemic stroke [13]. However, given the expression of $\mathrm{C} 3 \mathrm{aR}$ on astrocytes and microglia, $\mathrm{C} 3 \mathrm{a}$ may also exert its effects indirectly through glial C3aR, and the balance between neuronal and glial C3aR signaling may be developmentally regulated, Figure 2. Regardless of its cellular expression, $\mathrm{C} 3 \mathrm{aR}$ appears to be an attractive target for pharmacological manipulation to improve outcome after ischemic injury to both the adult and the immature brain.

While contributing to tissue injury in the acute period, C5a/C5aR1 signaling is required for optimal protective and reparatory astrocyte responses and for the formation of glial scar in the post-acute phase [112]. In a rodent model of amyotrophic lateral sclerosis, both the expression levels of $\mathrm{C} 5 \mathrm{aR} 1$ and the number of $\mathrm{C} 5 \mathrm{aR} 1$-expressing astrocytes 
increase in the spinal cord with disease progression [16]. Treatment with C5aR1 antagonist reduced astrocyte proliferation, slowed down the disease progression and extended survival [16]. C5aR2 has recently been shown to convey neuroprotection in a model of traumatic spinal cord injury [113]. C5aR2 knockdown increased the expression of nitric oxide synthase 2 and nuclear factor kappa B (NFkB) signaling in astrocytes, implicating $\mathrm{C} 5 \mathrm{aR} 2$ as a negative regulator of inflammation [86]. The above neuroprotective functions of $\mathrm{C} 5 \mathrm{aR} 2$ may therefore be astrocyte-mediated. However, as $\mathrm{C} 5 \mathrm{aR} 2$ is expressed by astrocytes, neurons as well as microglia [86,87], the specific roles of C5aR2 in these cell-types and under different disease conditions remain to be addressed, Figure 2.

\section{The Complement System: An Astrocyte Effector}

In the developing $\mathrm{CNS}$, astrocyte-derived TGF $\beta$ instructs neurons to tag weak synapses with $\mathrm{C} 1 \mathrm{q}$ [114], which then leads to the activation of the classical complement pathway and synapse elimination via the recognition of synapse-bound C3b by microglial CR3, and its subsequent phagocytosis [7,8]. The C1q and CR3-dependent phagocytosis is also of critical importance for the clearance of neurodegenerative debris by microglia after injury [10], although the specific role of astrocytes in this process is less understood. As mentioned above, binding of $\mathrm{C} 1 \mathrm{q}$ to a phagocytic receptor Megf10 is required for normal clearance of apoptotic cells by astrocytes [88]. Astrocyte Megf10 is also involved in developmental synaptic pruning and neuronal activity-dependent remodeling of synapses; however, the synapse engulfment by astrocytes is independent of $\mathrm{C} 1 \mathrm{q}[8,102]$. There is evidence pointing to the role of astrocyte-derived $\mathrm{C} 3$ and neuronal $\mathrm{C} 3 \mathrm{aR}$ signaling in synaptic plasticity and maintaining normal dendritic extension [17]. However, exposure to amyloid- $\beta$ activates astrocyte NFKB and triggers secretion of $\mathrm{C} 3$, which through subsequent excessive activation of $\mathrm{C} 3 \mathrm{aR}$ on neurons seems to impair dendritic morphology and alter excitatory synaptic function through dysregulation of intraneuronal calcium [17]. Moreover, in the Alzheimer's disease context, constitutive deficiency of $\mathrm{C} 3$ was protective against neurodegeneration and cognitive decline, despite higher amyloid- $\beta$ plaque load [115]. Astrocyte-secreted $\mathrm{C} 3$ signaling through $\mathrm{C} 3 \mathrm{aR}$ on microglia was proposed to contribute to tau-induced neurodegeneration by STAT3 activation leading to microglial reactivity [19]. Together with the evidence for the involvement of C3b in the loss of neuronal synapses $[8,18]$, these results indeed point to the role of astrocyte derived C3 in neurodegeneration induced by amyloid- $\beta$. The $\mathrm{C} 3-\mathrm{C} 3 \mathrm{aR}$ cross-talk between astrocytes and microglia drives astrocyte dysfunction, lesion development and functional impairment in a model of neuromyelitis optica [116], a rare neuroinflammatory demyelinating disease of the CNS characterized by the presence of autoantibodies against astrocyte water channel aquaporin 4, Figure 3.

In contrast, up-regulation of $\mathrm{C} 3$ in astrocytes was protective from neuronal damage and loss in the early stage of glaucoma [117]. In the same disease context, however, C1q, conceivably microglia-derived, was shown to play a deleterious role [118]. Thus, at least in some neurodegenerative conditions, $\mathrm{C} 1 \mathrm{q}$ and $\mathrm{C} 3$ may have independent or even opposing roles. In the post-acute and chronic phase after ischemic stroke, C3a-C3aR signaling stimulates neurogenesis, the increase in the density of excitatory synapses, and the expression of GAP43, a marker of axonal sprouting and glial plasticity in the peri-infarct region $[13,14]$. Although the origin of $\mathrm{C} 3 / \mathrm{C} 3 \mathrm{a}$ in the peri-infarct parenchyma was not investigated, it is conceivable that astrocytes and microglia are two major sources of C3. In light of the growing evidence for the role of intracellular C3 in survival and metabolic reprogramming of other cell types [34-37], functions of C3 in astrocyte resilience [119] ought to be considered. The specific involvement of astrocyte C3 in different disease conditions and disease stages warrants further investigation, Figure 3. 


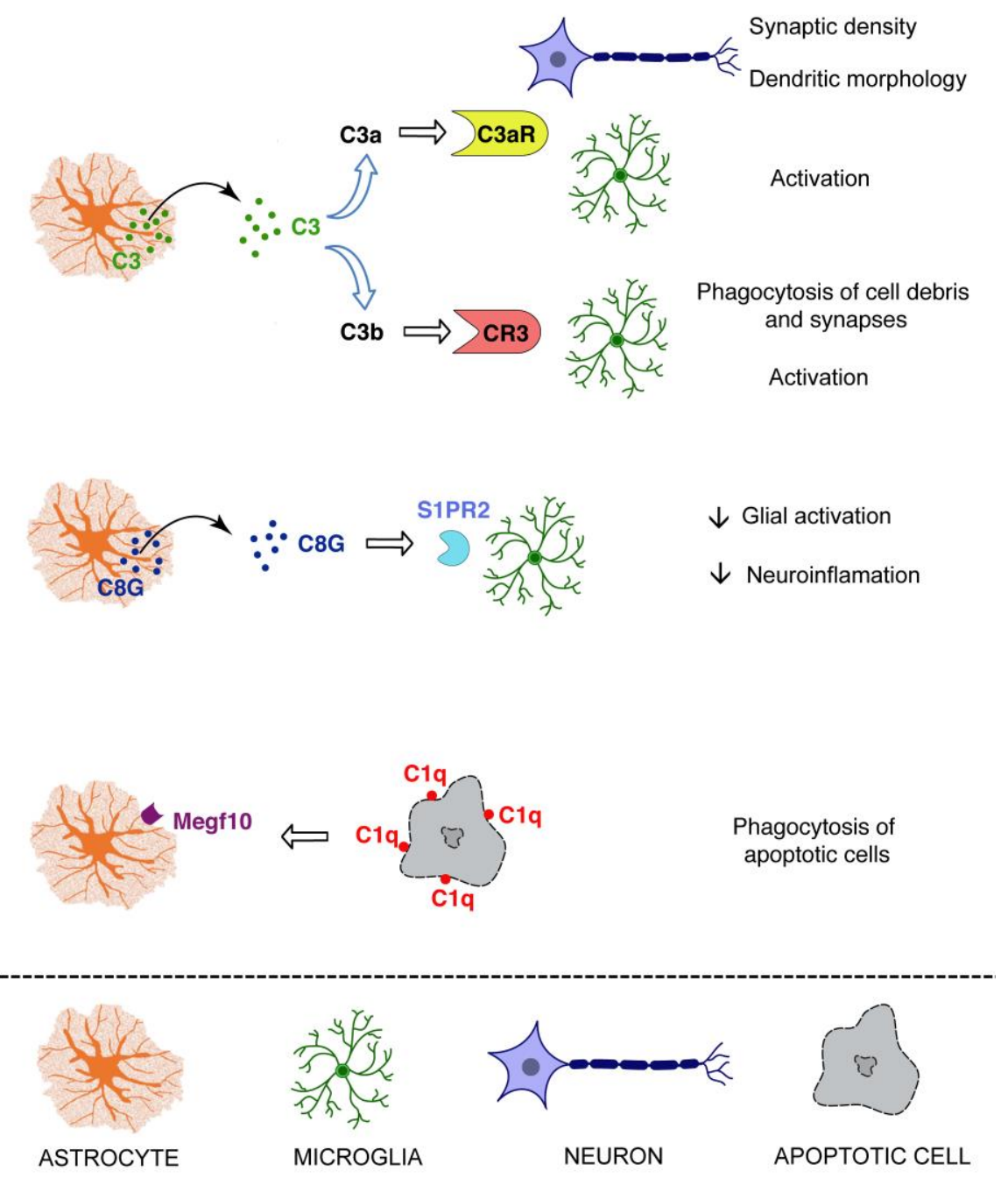

Figure 3. The complement system as an astrocyte effector. Astrocytes may exert some of their functions through the secretion of complement proteins, in particular $\mathrm{C} 3$ and the $\gamma$ subunit of C8 (C8G), or through the phagocytosis of C1q coated targets. S1PR2: sphingosine-1-phosphate receptor 2 .

A recent report pointed to a novel, complement activation-independent function of $\mathrm{C} 8$. The $\mathrm{C} 8 \gamma$ chain, one of the three subunits $(\alpha, \beta, \gamma)$ of $\mathrm{C} 8$, a component of the membrane attack complex, is present at high levels in the brain tissue, cerebrospinal fluid, and plasma of Alzheimer's disease patients [120]. Importantly, C8 $\gamma$ is secreted by astrocytes, inhibits glial hyperactivation, neuroinflammation, and cognitive decline in acute and chronic animal models of Alzheimer's disease, and exerts its anti-inflammatory effects via microglial sphingosine-1-phosphate receptor 2 [120], Figure 3.

\section{The Complement System: A Marker of Astrocyte Phenotype?}

Using transcriptomic data analysis, C3 was shown to be expressed by astrocytes isolated from brain tissue from several different acute and chronic neurodegenerative conditions and was put forward as a marker of what some authors referred to as the neurotoxic (A1) astrocytes [98]. However, C3 is also expressed in so called neuroprotective astrocytes (A2) [100] and microglia [99,121]. As detailed above, the exact functions of astrocyte C3 (secreted or intracellular) are not equivocal. They are complex, and context-dependent, and they are far from elucidated. For this and many other reasons, the misleading simplistic view and the binary division of reactive astrocytes into neuroprotective and neurotoxic were recently proposed to be abandoned, and this consensus view received a wide support 
from the astrocyte community [41]. The heterogeneity of reactive astrocytes, not least with regard to the expression of genes coding for complement proteins and receptors and their context-dependent functions, deserves further investigation.

\section{Conclusions}

Although the first report on the expression of complement proteins and receptors in astrocytes dates back more than 30 years [122], the full complexity of the multiple roles of complement in these cells is only now being appreciated. The scientific endeavor in search of novel functions of complement in the CNS is more active than ever. The rewards will come in the form of detailed understanding of the intricate cross-talk between neural cells and the roles of complement in the healthy CNS and a whole range of neurological diseases. Most likely they will also result in the identification of novel disease-specific strategies to reverse astrocyte dysfunction and modulate reactive gliosis for the treatment of neurodegenerative disorders and other pathological conditions affecting the CNS.

Funding: The authors' research has been supported by the Swedish Medical Research Council (201702255 and 2017-00991), ALF Gothenburg (146051 and 716591), AFA Research Foundation, Söderberg's Foundations, Sten A. Olsson Foundation for Research and Culture, Hjärnfonden, Hagströmer's Foundation Millennium, Amlöv's Foundation, E. Jacobson's Donation Fund, VINNOVA, the Swedish Stroke Foundation, NanoNet COST Action (BM1002), and EU FP 7 Program TargetBraIn (279017).

Acknowledgments: The authors would like to thank Anna Stokowska for help with the preparation of the figures. We acknowledge EuroCellNet COST Action (CA15214) for promoting novel research interactions in this field.

Conflicts of Interest: The authors declare no conflict of interest.

\section{References}

1. Shinjyo, N.; Ståhlberg, A.; Dragunow, M.; Pekny, M.; Pekna, M. Complement-derived anaphylatoxin C3a regulates in vitro differentiation and migration of neural progenitor cells in vitro. Stem Cells 2009, 27, 2824-2832. [CrossRef] [PubMed]

2. Coulthard, L.G.; Hawksworth, O.A.; Li, R.; Balachandran, A.; Lee, J.D.; Sepehrband, F.; Kurniawan, N.; Jeanes, A.; Simmons, D.G.; Wolvetang, E.; et al. Complement C5aR1 Signaling Promotes Polarization and Proliferation of Embryonic Neural Progenitor Cells through PKCzeta. J. Neurosci. 2017, 37, 5395-5407. [CrossRef]

3. Gorelik, A.; Sapir, T.; Ben-Reuven, L.; Reiner, O. Complement C3 Affects Rac1 Activity in the Developing Brain. Front. Mol. Neurosci. 2018, 11. [CrossRef] [PubMed]

4. Gorelik, A.; Sapir, T.; Haffner-Krausz, R.; Olender, T.; Woodruff, T.M.; Reiner, O. Developmental activities of the complement pathway in migrating neurons. Nat. Commun. 2017, 8, 15096. [CrossRef] [PubMed]

5. Coulthard, L.G.; Hawksworth, O.A.; Conroy, J.; Lee, J.D.; Woodruff, T.M. Complement C3a receptor modulates embryonic neural progenitor cell proliferation and cognitive performance. Mol. Immunol. 2018, 101, 176-181. [CrossRef] [PubMed]

6. Pozo-Rodrigálvarez, A.; Ollaranta, R.; Skoog, J.; Pekny, M.; Pekna, M. Hyperactive behavior and altered brain morphology in adult complement C3a receptor deficient mice. Front. Immunol. 2021, 12, 604812. [CrossRef]

7. Schafer, D.P.; Lehrman, E.K.; Kautzman, A.G.; Koyama, R.; Mardinly, A.R.; Yamasak, R.; Ransohoff, R.M.; Greenberg, M.E.; Barres, B.A.; Stevens, B. Microglia sculpt postnatal neural circuits in an activity and complement-dependent manner. Neuron 2012, 74, 691-705. [CrossRef]

8. Stevens, B.; Allen, N.J.; Vazquez, L.E.; Howell, G.R.; Christopherson, K.S.; Nouri, N.; Micheva, K.D.; Mehalow, A.K.; Huberman, A.D.; Stafford, B.; et al. The classical complement cascade mediates CNS synapse elimination. Cell 2007, 131, 1164-1178. [CrossRef]

9. Rahpeymai, Y.; Hietala, M.A.; Wilhelmsson, U.; Fotheringham, A.; Davies, I.; Nilsson, A.K.; Zwirner, J.; Wetsel, R.A.; Gerard, C.; Pekny, M.; et al. Complement: A novel factor in basal and ischemia-induced neurogenesis. EMBO J. 2006, 25, $1364-1374$. [CrossRef]

10. Norris, G.T.; Smirnov, I.; Filiano, A.J.; Shadowen, H.M.; Cody, K.R.; Thompson, J.A.; Harris, T.H.; Gaultier, A.; Overall, C.C.; Kipnis, J. Neuronal integrity and complement control synaptic material clearance by microglia after CNS injury. J. Exp. Med. 2018, 215, 1789-1801. [CrossRef]

11. Gong, B.; Pan, Y.; Zhao, W.; Knable, L.; Vempati, P.; Begum, S.; Ho, L.; Wang, J.; Yemul, S.; Barnum, S.; et al. IVIG immunotherapy protects against synaptic dysfunction in Alzheimer's disease through complement anaphylatoxin C5a-mediated AMPA-CREBC/EBP signaling pathway. Mol. Immunol. 2013, 56, 619-629. [CrossRef] [PubMed]

12. Perez-Alcazar, M.; Daborg, J.; Stokowska, A.; Wasling, P.; Björefeldt, A.; Kalm, M.; Zetterberg, H.; Carlström, K.E.; Blomgren, K.; Ekdahl, C.T.; et al. Altered cognitive performance and synaptic function in the hippocampus of mice lacking C3. Exp. Neurol. 2014, 253, 154-164. [CrossRef] [PubMed] 
13. Stokowska, A.; Atkins, A.L.; Moran, J.; Pekny, T.; Bulmer, L.; Pascoe, M.C.; Barnum, S.R.; Wetsel, R.A.; Nilsson, J.; Dragunow, M.; et al. Complement peptide C3a stimulates neural plasticity after experimental brain ischemia. Brain 2017, 140, 353-369. [CrossRef]

14. Stokowska, A.; Pekna, M. Complement C3a: Shaping the plasticity of the post-stroke brain. In Cellular and Molecular Approaches to Regeneration E Repair; Springer Series in Translational Stroke Research; Lapchak, P.A., Zhang, J.H., Eds.; Springer: Cham, Switzerland, 2018; pp. 521-541.

15. Shi, Q.; Colodner, K.J.; Matousek, S.B.; Merry, K.; Hong, S.; Kenison, J.E.; Frost, J.L.; Le, K.X.; Li, S.; Dodart, J.C.; et al. Complement C3-Deficient Mice Fail to Display Age-Related Hippocampal Decline. J. Neurosci. 2015, 35, 13029-13042. [CrossRef] [PubMed]

16. Woodruff, T.M.; Costantini, K.J.; Crane, J.W.; Atkin, J.D.; Monk, P.N.; Taylor, S.M.; Noakes, P.G. The complement factor C5a contributes to pathology in a rat model of amyotrophic lateral sclerosis. J. Immunol. 2008, 181, 8727-8734. [CrossRef]

17. Lian, H.; Yang, L.; Cole, A.; Sun, L.; Chiang, A.C.; Fowler, S.W.; Shim, D.J.; Rodriguez-Rivera, J.; Taglialatela, G.; Jankowsky, J.L.; et al. NFkappaB-activated astroglial release of complement C3 compromises neuronal morphology and function associated with Alzheimer's disease. Neuron 2015, 85, 101-115. [CrossRef]

18. Hong, S.; Beja-Glasser, V.F.; Nfonoyim, B.M.; Frouin, A.; Li, S.; Ramakrishnan, S.; Merry, K.M.; Shi, Q.; Rosenthal, A.; Barres, B.A.; et al. Complement and microglia mediate early synapse loss in Alzheimer mouse models. Science 2016, 352, 712-716. [CrossRef]

19. Litvinchuk, A.; Wan, Y.W.; Swartzlander, D.B.; Chen, F.; Cole, A.; Propson, N.E.; Wang, Q.; Zhang, B.; Liu, Z.; Zheng, H. Complement C3aR Inactivation Attenuates Tau Pathology and Reverses an Immune Network Deregulated in Tauopathy Models and Alzheimer's Disease. Neuron 2018, 100, 1337-1353.e1335. [CrossRef]

20. Dejanovic, B.; Huntley, M.A.; De Mazière, A.; Meilandt, W.J.; Wu, T.; Srinivasan, K.; Jiang, Z.; Gandham, V.; Friedman, B.A.; Ngu, H.; et al. Changes in the Synaptic Proteome in Tauopathy and Rescue of Tau-Induced Synapse Loss by C1q Antibodies. Neuron 2018, 100, 1322-1336.e1327. [CrossRef]

21. Wu, T.; Dejanovic, B.; Gandham, V.D.; Gogineni, A.; Edmonds, R.; Schauer, S.; Srinivasan, K.; Huntley, M.A.; Wang, Y.; Wang, T.M.; et al. Complement C3 Is Activated in Human AD Brain and Is Required for Neurodegeneration in Mouse Models of Amyloidosis and Tauopathy. Cell Rep. 2019, 28, 2111-2123.e2116. [CrossRef]

22. Schartz, N.D.; Tenner, A.J. The good, the bad, and the opportunities of the complement system in neurodegenerative disease. J. Neuroinflamm. 2020, 17, 354. [CrossRef]

23. Berends, E.T.; Kuipers, A.; Ravesloot, M.M.; Urbanus, R.T.; Rooijakkers, S.H. Bacteria under stress by complement and coagulation. FEMS Microbiol. Rev. 2014, 38, 1146-1171. [CrossRef]

24. Bajic, G.; Degn, S.E.; Thiel, S.; Andersen, G.R. Complement activation, regulation, and molecular basis for complement-related diseases. EMBO J. 2015, 34, 2735-2757. [CrossRef]

25. Matsushita, M.; Fujita, T. Cleavage of the third component of complement (C3) by mannose-binding protein-associated serine protease (MASP) with subsequent complement activation. Immunobiology 1995, 194, 443-448. [CrossRef]

26. Liszewski, M.K.; Kolev, M.; Le Friec, G.; Leung, M.; Bertram, P.G.; Fara, A.F.; Subias, M.; Pickering, M.C.; Drouet, C.; Meri, S.; et al. Intracellular complement activation sustains T cell homeostasis and mediates effector differentiation. Immunity 2013, 39, 1143-1157. [CrossRef]

27. Yuan, X.; Shan, M.; You, R.; Frazier, M.V.; Hong, M.J.; Wetsel, R.A.; Drouin, S.; Seryshev, A.; Song, L.Z.; Cornwell, L.; et al. Activation of C3a receptor is required in cigarette smoke-mediated emphysema. Mucosal. Immunol. 2015, 8, 874-885. [CrossRef] [PubMed]

28. Johnson, U.; Ohlsson, K.; Olsson, I. Effects of granulocyte neutral proteases on complement components. Scand. J. Immunol. 1976, 5, 421-426. [CrossRef] [PubMed]

29. Markiewski, M.M.; Lambris, J.D. The role of complement in inflammatory diseases from behind the scenes into the spotlight. Am. J. Pathol. 2007, 171, 715-727. [CrossRef] [PubMed]

30. Amara, U.; Flierl, M.A.; Rittirsch, D.; Klos, A.; Chen, H.; Acker, B.; Bruckner, U.B.; Nilsson, B.; Gebhard, F.; Lambris, J.D.; et al. Molecular intercommunication between the complement and coagulation systems. J. Immunol. 2010, 185, 5628-5636. [CrossRef] [PubMed]

31. Klos, A.; Tenner, A.J.; Johswich, K.O.; Ager, R.R.; Reis, E.S.; Kohl, J. The role of the anaphylatoxins in health and disease. Mol. Immunol. 2009, 46, 2753-2766. [CrossRef] [PubMed]

32. Chen, N.J.; Mirtsos, C.; Suh, D.; Lu, Y.C.; Lin, W.J.; McKerlie, C.; Lee, T.; Baribault, H.; Tian, H.; Yeh, W.C. C5L2 is critical for the biological activities of the anaphylatoxins C5a and C3a. Nature 2007, 446, 203-207. [CrossRef]

33. Li, X.X.; Lee, J.D.; Kemper, C.; Woodruff, T.M. The Complement Receptor C5aR2: A Powerful Modulator of Innate and Adaptive Immunity. J. Immunol. 2019, 202, 3339-3348. [CrossRef] [PubMed]

34. Dos Santos, R.S.; Marroqui, L.; Grieco, F.A.; Marselli, L.; Suleiman, M.; Henz, S.R.; Marchetti, P.; Wernersson, R.; Eizirik, D.L. Protective Role of Complement C3 Against Cytokine-Mediated $\beta$-Cell Apoptosis. Endocrinology 2017, 158, 2503-2521. [CrossRef] [PubMed]

35. Kulkarni, H.S.; Elvington, M.L.; Perng, Y.C.; Liszewski, M.K.; Byers, D.E.; Farkouh, C.; Yusen, R.D.; Lenschow, D.J.; Brody, S.L.; Atkinson, J.P. Intracellular C3 Protects Human Airway Epithelial Cells from Stress-associated Cell Death. Am. J. Respir. Cell Mol. Biol. 2019, 60, 144-157. [CrossRef] [PubMed]

36. King, B.C.; Renström, E.; Blom, A.M. Intracellular cytosolic complement component C3 regulates cytoprotective autophagy in pancreatic beta cells by interaction with ATG16L1. Autophagy 2019, 15, 919-921. [CrossRef] [PubMed] 
37. Liszewski, M.K.; Elvington, M.; Kulkarni, H.S.; Atkinson, J.P. Complement's hidden arsenal: New insights and novel functions inside the cell. Mol. Immunol. 2017, 84, 2-9. [CrossRef] [PubMed]

38. Elvington, M.; Liszewski, M.K.; Bertram, P.; Kulkarni, H.S.; Atkinson, J.P. A C3(H20) recycling pathway is a component of the intracellular complement system. J. Clin. Investig. 2017, 127, 970-981. [CrossRef]

39. Pekny, M.; Pekna, M. Astrocyte reactivity and reactive astrogliosis: Costs and benefits. Physiol. Rev. 2014, 94, 1077-1098. [CrossRef]

40. Verkhratsky, A.; Nedergaard, M. Physiology of Astroglia. Physiol. Rev. 2018, 98, 239-389. [CrossRef]

41. Escartin, C.; Galea, E.; Lakatos, A.; O'Callaghan, J.P.; Petzold, G.C.; Serrano-Pozo, A.; Steinhäuser, C.; Volterra, A.; Carmignoto, G.; Agarwal, A.; et al. Reactive astrocyte nomenclature, definitions, and future directions. Nat. Neurosci. 2021, 24, 312-325. [CrossRef]

42. Bushong, E.A.; Martone, M.E.; Jones, Y.Z.; Ellisman, M.H. Protoplasmic astrocytes in CA1 stratum radiatum occupy separate anatomical domains. J. Neurosci. 2002, 22, 183-192. [CrossRef]

43. Iadecola, C.; Nedergaard, M. Glial regulation of the cerebral microvasculature. Nat. Neurosci. 2007, 10, 1369-1376. [CrossRef]

44. Ullian, E.M.; Sapperstein, S.K.; Christopherson, K.S.; Barres, B.A. Control of synapse number by glia. Science 2001, $291,657-661$. [CrossRef]

45. Koehler, R.C.; Roman, R.J.; Harder, D.R. Astrocytes and the regulation of cerebral blood flow. Trends Neurosci. 2009, 32, 160-169. [CrossRef] [PubMed]

46. Mulligan, S.J.; MacVicar, B.A. Calcium transients in astrocyte endfeet cause cerebrovascular constrictions. Nature 2004, 431, 195-199. [CrossRef]

47. Christopherson, K.S.; Ullian, E.M.; Stokes, C.C.; Mullowney, C.E.; Hell, J.W.; Agah, A.; Lawler, J.; Mosher, D.F.; Bornstein, P.; Barres, B.A. Thrombospondins are astrocyte-secreted proteins that promote CNS synaptogenesis. Cell 2005, 120, 421-433. [CrossRef] [PubMed]

48. Eroglu, C.; Allen, N.J.; Susman, M.W.; O’Rourke, N.A.; Park, C.Y.; Ozkan, E.; Chakraborty, C.; Mulinyawe, S.B.; Annis, D.S.; Huberman, A.D.; et al. Gabapentin receptor alpha2delta-1 is a neuronal thrombospondin receptor responsible for excitatory CNS synaptogenesis. Cell 2009, 139, 380-392. [CrossRef]

49. Kucukdereli, H.; Allen, N.J.; Lee, A.T.; Feng, A.; Ozlu, M.I.; Conatser, L.M.; Chakraborty, C.; Workman, G.; Weaver, M.; Sage, E.H.; et al. Control of excitatory CNS synaptogenesis by astrocyte-secreted proteins Hevin and SPARC. Proc. Natl. Acad. Sci. USA 2011, 108, E440-E449. [CrossRef]

50. Allen, N.J.; Bennett, M.L.; Foo, L.C.; Wang, G.X.; Chakraborty, C.; Smith, S.J.; Barres, B.A. Astrocyte glypicans 4 and 6 promote formation of excitatory synapses via GluA1 AMPA receptors. Nature 2012, 486, 410-414. [CrossRef]

51. Stogsdill, J.A.; Ramirez, J.; Liu, D.; Kim, Y.H.; Baldwin, K.T.; Enustun, E.; Ejikeme, T.; Ji, R.R.; Eroglu, C. Astrocytic neuroligins control astrocyte morphogenesis and synaptogenesis. Nature 2017, 551, 192-197. [CrossRef] [PubMed]

52. Iliff, J.J.; Wang, M.; Liao, Y.; Plogg, B.A.; Peng, W.; Gundersen, G.A.; Benveniste, H.; Vates, G.E.; Deane, R.; Goldman, S.A.; et al. A paravascular pathway facilitates CSF flow through the brain parenchyma and the clearance of interstitial solutes, including amyloid $\beta$. Sci. Transl. Med. 2012, 4, 147ra111. [CrossRef] [PubMed]

53. Rasmussen, M.K.; Mestre, H.; Nedergaard, M. Fluid Transport in the Brain. Physiol. Rev. 2021. [CrossRef] [PubMed]

54. Pekny, M.; Pekna, M. Reactive gliosis in the pathogenesis of CNS diseases. Biochim. Biophys. Acta 2016, 1862, 483-491. [CrossRef]

55. Pekny, M.; Pekna, M.; Messing, A.; Steinhäuser, C.; Lee, J.M.; Parpura, V.; Hol, E.M.; Sofroniew, M.V.; Verkhratsky, A. Astrocytes: A central element in neurological diseases. Acta Neuropathol. 2016, 131, 323-345. [CrossRef] [PubMed]

56. Sofroniew, M.V.; Vinters, H.V. Astrocytes: Biology and pathology. Acta Neuropathol. 2010, 119, 7-35. [CrossRef] [PubMed]

57. Sofroniew, M.V. Molecular dissection of reactive astrogliosis and glial scar formation. Trends Neurosci. 2009, 32, 638-647. [CrossRef]

58. Buffo, A.; Rite, I.; Tripathi, P.; Lepier, A.; Colak, D.; Horn, A.P.; Mori, T.; Götz, M. Origin and progeny of reactive gliosis: A source of multipotent cells in the injured brain. Proc. Natl. Acad. Sci. USA 2008, 105, 3581-3586. [CrossRef] [PubMed]

59. Pekny, M.; Nilsson, M. Astrocyte activation and reactive gliosis. Glia 2005, 50, 427-434. [CrossRef]

60. Zhang, Y.; Barres, B.A. Astrocyte heterogeneity: An underappreciated topic in neurobiology. Curr. Opin. Neurobiol. 2010, 20, 588-594. [CrossRef] [PubMed]

61. Pekny, M.; Wilhelmsson, U.; Tatlisumak, T.; Pekna, M. Astrocyte activation and reactive gliosis-A new target in stroke? Neurosci. Lett. 2019, 689, 45-55. [CrossRef]

62. Göritz, C.; Dias, D.O.; Tomilin, N.; Barbacid, M.; Shupliakov, O.; Frisén, J. A pericyte origin of spinal cord scar tissue. Science 2011, 333, 238-242. [CrossRef]

63. Balasingam, V.; Dickson, K.; Brade, A.; Yong, V.W. Astrocyte reactivity in neonatal mice: Apparent dependence on the presence of reactive microglia/macrophages. Glia 1996, 18, 11-26. [CrossRef]

64. Hostenbach, S.; Cambron, M.; D’Haeseleer, M.; Kooijman, R.; De Keyser, J. Astrocyte loss and astrogliosis in neuroinflammatory disorders. Neurosci. Lett. 2014, 565, 39-41. [CrossRef]

65. Klein, M.A.; Möller, J.C.; Jones, L.L.; Bluethmann, H.; Kreutzberg, G.W.; Raivich, G. Impaired neuroglial activation in interleukin-6 deficient mice. Glia 1997, 19, 227-233. [CrossRef]

66. Rabchevsky, A.G.; Weinitz, J.M.; Coulpier, M.; Fages, C.; Tinel, M.; Junier, M.P. A role for transforming growth factor alpha as an inducer of astrogliosis. J. Neurosci. 1998, 18, 10541-10552. [CrossRef] [PubMed] 
67. Sriram, K.; Benkovic, S.A.; Hebert, M.A.; Miller, D.B.; O'Callaghan, J.P. Induction of gp130-related cytokines and activation of JAK2/STAT3 pathway in astrocytes precedes up-regulation of glial fibrillary acidic protein in the 1-methyl-4-phenyl-1,2,3,6tetrahydropyridine model of neurodegeneration: Key signaling pathway for astrogliosis in vivo? J. Biol. Chem. 2004, 279, 19936-19947. [CrossRef] [PubMed]

68. Winter, C.G.; Saotome, Y.; Levison, S.W.; Hirsh, D. A role for ciliary neurotrophic factor as an inducer of reactive gliosis, the glial response to central nervous system injury. Proc. Natl. Acad. Sci. USA 1995, 92, 5865-5869. [CrossRef]

69. Bardehle, S.; Kruger, M.; Buggenthin, F.; Schwausch, J.; Ninkovic, J.; Clevers, H.; Snippert, H.J.; Theis, F.J.; Meyer-Luehmann, M.; Bechmann, I.; et al. Live imaging of astrocyte responses to acute injury reveals selective juxtavascular proliferation. Nat. Neurosci. 2013, 16, 580-586. [CrossRef] [PubMed]

70. Wilhelmsson, U.; Bushong, E.A.; Price, D.L.; Smarr, B.L.; Phung, V.; Terada, M.; Ellisman, M.H.; Pekny, M. Redefining the concept of reactive astrocytes as cells that remain within their unique domains upon reaction to injury. Proc. Natl. Acad. Sci. USA 2006, 103, 17513-17518. [CrossRef]

71. Wilhelmsson, U.; Lebkuechner, I.; Leke, R.; Marasek, P.; Yang, X.; Antfolk, D.; Chen, M.; Mohseni, P.; Lasic, E.; Bobnar, S.T.; et al. Nestin Regulates Neurogenesis in Mice Through Notch Signaling From Astrocytes to Neural Stem Cells. Cereb. Cortex 2019, 29, 4050-4066. [CrossRef]

72. Eliasson, C.; Sahlgren, C.; Berthold, C.H.; Stakeberg, J.; Celis, J.E.; Betsholtz, C.; Eriksson, J.E.; Pekny, M. Intermediate filament partnership in astrocytes. J. Biol. Chem. 1999, 274, 23996-24006. [CrossRef]

73. Hol, E.M.; Pekny, M. Glial fibrillary acidic protein (GFAP) and the astrocyte intermediate filament system in diseases of the central nervous system. Curr. Opin. Cell Biol. 2015, 32, 121-130. [CrossRef] [PubMed]

74. Jing, R.; Wilhelmsson, U.; Goodwill, W.; Li, L.; Pan, Y.; Pekny, M.; Skalli, O. Synemin is expressed in reactive astrocytes in neurotrauma and interacts differentially with vimentin and GFAP intermediate filament networks. J. Cell Sci. 2007, 120, $1267-1277$. [CrossRef] [PubMed]

75. Pekny, T.; Faiz, M.; Wilhelmsson, U.; Curtis, M.A.; Matej, R.; Skalli, O.; Pekny, M. Synemin is expressed in reactive astrocytes and Rosenthal fibers in Alexander disease. Apmis 2014, 122, 76-80. [CrossRef]

76. Eriksson, J.E.; Dechat, T.; Grin, B.; Helfand, B.; Mendez, M.; Pallari, H.M.; Goldman, R.D. Introducing intermediate filaments: From discovery to disease. J. Clin. Investig. 2009, 119, 1763-1771. [CrossRef] [PubMed]

77. Lu, Y.B.; Iandiev, I.; Hollborn, M.; Körber, N.; Ulbricht, E.; Hirrlinger, P.G.; Pannicke, T.; Wei, E.Q.; Bringmann, A.; Wolburg, H.; et al. Reactive glial cells: Increased stiffness correlates with increased intermediate filament expression. FASEB J. 2011, 25, 624-631. [CrossRef]

78. Pallari, H.M.; Eriksson, J.E. Intermediate filaments as signaling platforms. Sci. STKE 2006, 2006, pe53. [CrossRef]

79. Lepekhin, E.A.; Eliasson, C.; Berthold, C.H.; Berezin, V.; Bock, E.; Pekny, M. Intermediate filaments regulate astrocyte motility. J. Neurochem. 2001, 79, 617-625. [CrossRef]

80. Gasque, P.; Chan, P.; Fontaine, M.; Ischenko, A.; Lamacz, M.; Gotze, O.; Morgan, B.P. Identification and characterization of the complement C5a anaphylatoxin receptor on human astrocytes. J. Immunol. 1995, 155, 4882-4889.

81. Ischenko, A.; Sayah, S.; Patte, C.; Andreev, S.; Gasque, P.; Schouft, M.; Vaudry, H.; Fontaine, M. Expression of a functional anaphylatoxin C3a receptor by astrocytes. J. Neurochem. 1998, 71, 2487-2496. [CrossRef] [PubMed]

82. Shinjyo, N.; de Pablo, Y.; Pekny, M.; Pekna, M. Complement peptide C3a promotes astrocyte survival in response to ischemic stress. Mol. Neurobiol. 2016, 53, 3076-3087. [CrossRef]

83. Sayah, S.; Ischenko, A.; Zhakhov, A.; Bonnard, A.S.; Fontaine, M. Expression of cytokines by human astrocytomas following stimulation by C3a and C5a anaphylatoxins: Specific increase in interleukin-6 mRNA expression. J. Neurochem. 1999, 72, 2426-2436. [CrossRef]

84. Sayah, S.; Jauneau, A.C.; Patte, C.; Tonon, M.C.; Vaudry, H.; Fontaine, M. Two different transduction pathways are activated by C3a and C5a anaphylatoxins on astrocytes. Mol. Brain Res. 2003, 112, 53-60. [CrossRef]

85. Nataf, S.; Davoust, N.; Barnum, S.R. Kinetics of anaphylatoxin C5a receptor expression during experimental allergic encephalomyelitis. J. Neuroimmunol. 1998, 91, 147-155. [CrossRef]

86. Gavrilyuk, V.; Kalinin, S.; Hilbush, B.S.; Middlecamp, A.; McGuire, S.; Pelligrino, D.; Weinberg, G.; Feinstein, D.L. Identification of complement 5a-like receptor (C5L2) from astrocytes: Characterization of anti-inflammatory properties. J. Neurochem. 2005, 92, 1140-1149. [CrossRef] [PubMed]

87. Zhang, Y.; Chen, K.; Sloan, S.A.; Bennett, M.L.; Scholze, A.R.; O’Keeffe, S.; Phatnani, H.P.; Guarnieri, P.; Caneda, C.; Ruderisch, N.; et al. An RNA-sequencing transcriptome and splicing database of glia, neurons, and vascular cells of the cerebral cortex. $J$. Neurosci. 2014, 34, 11929-11947. [CrossRef]

88. Iram, T.; Ramirez-Ortiz, Z.; Byrne, M.H.; Coleman, U.A.; Kingery, N.D.; Means, T.K.; Frenkel, D.; El Khoury, J. Megf10 Is a Receptor for C1Q That Mediates Clearance of Apoptotic Cells by Astrocytes. J. Neurosci. 2016, 36, 5185-5192. [CrossRef] [PubMed]

89. Ghebrehiwet, B.; Peerschke, E.I. cC1q-R (calreticulin) and gC1q-R/p33: Ubiquitously expressed multi-ligand binding cellular proteins involved in inflammation and infection. Mol. Immunol. 2004, 41, 173-183. [CrossRef]

90. Fernando, L.P.; Natesan, S.; Joseph, K.; Kaplan, A.P. High molecular weight kininogen and factor XII binding to endothelial cells and astrocytes. Thromb. Haemost. 2003, 90, 787-795. [CrossRef]

91. Crossin, K.L.; Tai, M.H.; Krushel, L.A.; Mauro, V.P.; Edelman, G.M. Glucocorticoid receptor pathways are involved in the inhibition of astrocyte proliferation. Proc. Natl. Acad. Sci. USA 1997, 94, 2687-2692. [CrossRef] 
92. Duus, K.; Hansen, E.W.; Tacnet, P.; Frachet, P.; Arlaud, G.J.; Thielens, N.M.; Houen, G. Direct interaction between CD91 and C1q. FEBS J. 2010, 277, 3526-3537. [CrossRef] [PubMed]

93. Xing, P.; Liao, Z.; Ren, Z.; Zhao, J.; Song, F.; Wang, G.; Chen, K.; Yang, J. Roles of low-density lipoprotein receptor-related protein 1 in tumors. Chin. J. Cancer 2016, 35, 6. [CrossRef]

94. Liang, Q.; Su, L.; Zhang, D.; Jiao, J. CD93 negatively regulates astrogenesis in response to MMRN2 through the transcriptional repressor ZFP503 in the developing brain. Proc. Natl. Acad. Sci. USA 2020, 117, 9413-9422. [CrossRef]

95. Fonseca, M.I.; Chu, S.; Pierce, A.L.; Brubaker, W.D.; Hauhart, R.E.; Mastroeni, D.; Clarke, E.V.; Rogers, J.; Atkinson, J.P.; Tenner, A.J. Analysis of the Putative Role of CR1 in Alzheimer's Disease: Genetic Association, Expression and Function. PLoS ONE 2016, 11, e0149792. [CrossRef] [PubMed]

96. Gasque, P.; Chan, P.; Mauger, C.; Schouft, M.T.; Singhrao, S.; Dierich, M.P.; Morgan, B.P.; Fontaine, M. Identification and characterization of complement C3 receptors on human astrocytes. J. Immunol. 1996, 156, 2247-2255.

97. Shinozaki, Y.; Shibata, K.; Yoshida, K.; Shigetomi, E.; Gachet, C.; Ikenaka, K.; Tanaka, K.F.; Koizumi, S. Transformation of Astrocytes to a Neuroprotective Phenotype by Microglia via P2Y(1) Receptor Downregulation. Cell Rep. 2017, 19, 1151-1164. [CrossRef] [PubMed]

98. Liddelow, S.A.; Guttenplan, K.A.; Clarke, L.E.; Bennett, F.C.; Bohlen, C.J.; Schirmer, L.; Bennett, M.L.; Munch, A.E.; Chung, W.S.; Peterson, T.C.; et al. Neurotoxic reactive astrocytes are induced by activated microglia. Nature 2017, 541, 481-487. [CrossRef] [PubMed]

99. Guttikonda, S.R.; Sikkema, L.; Tchieu, J.; Saurat, N.; Walsh, R.M.; Harschnitz, O.; Ciceri, G.; Sneeboer, M.; Mazutis, L.; Setty, M.; et al. Fully defined human pluripotent stem cell-derived microglia and tri-culture system model C3 production in Alzheimer's disease. Nat. Neurosci. 2021, 24, 343-354. [CrossRef]

100. Clarke, L.E.; Liddelow, S.A.; Chakraborty, C.; Munch, A.E.; Heiman, M.; Barres, B.A. Normal aging induces A1-like astrocyte reactivity. Proc. Natl. Acad. Sci. USA 2018, 115, E1896-E1905. [CrossRef]

101. Stephan, A.H.; Madison, D.V.; Mateos, J.M.; Fraser, D.A.; Lovelett, E.A.; Coutellier, L.; Kim, L.; Tsai, H.H.; Huang, E.J.; Rowitch, D.H.; et al. A dramatic increase of C1q protein in the CNS during normal aging. J. Neurosci. 2013, 33, 13460-13474. [CrossRef]

102. Chung, W.S.; Clarke, L.E.; Wang, G.X.; Stafford, B.K.; Sher, A.; Chakraborty, C.; Joung, J.; Foo, L.C.; Thompson, A.; Chen, C.; et al. Astrocytes mediate synapse elimination through MEGF10 and MERTK pathways. Nature 2013, 504, 394-400. [CrossRef]

103. Lian, H.; Litvinchuk, A.; Chiang, A.C.; Aithmitti, N.; Jankowsky, J.L.; Zheng, H. Astrocyte-Microglia Cross Talk through Complement Activation Modulates Amyloid Pathology in Mouse Models of Alzheimer's Disease. J. Neurosci. 2016, 36, 577-589. [CrossRef]

104. Davoust, N.; Jones, J.; Stahel, P.F.; Ames, R.S.; Barnum, S.R. Receptor for the C3a anaphylatoxin is expressed by neurons and glial cells. Glia 1999, 26, 201-211. [CrossRef]

105. Van Beek, J.; Bernaudin, M.; Petit, E.; Gasque, P.; Nouvelot, A.; MacKenzie, E.T.; Fontaine, M. Expression of receptors for complement anaphylatoxins C3a and C5a following permanent focal cerebral ischemia in the mouse. Exp. Neurol. 2000, 161, 373-382. [CrossRef]

106. Jauneau, A.-C.; Ischenko, A.; Chatagner, A.; Benard, M.; Chan, P.; Schouft, M.-T.; Patte, C.; Vaudry, H.; Fontaine, M. Interleukin-1 $\beta$ and anaphylatoxins exert a synergistic effect on NGF expression by astrocytes. J. Neuroinflamm. 2006, 3, 8. [CrossRef]

107. Jauneau, A.C.; Ischenko, A.; Chan, P.; Fontaine, M. Complement component anaphylatoxins upregulate chemokine expression by human astrocytes. FEBS Lett. 2003, 537, 17-22. [CrossRef]

108. Van Beek, J.; Nicole, O.; Ali, C.; Ischenko, A.; MacKenzie, E.T.; Buisson, A.; Fontaine, M. Complement anaphylatoxin C3a is selectively protective against NMDA-induced neuronal cell death. Neuroreport 2001, 12, 289-293. [CrossRef] [PubMed]

109. Järlestedt, K.; Rousset, C.I.; Ståhlberg, A.; Sourkova, H.; Atkins, A.L.; Thornton, C.; Barnum, S.R.; Wetsel, R.A.; Dragunow, M.; Pekny, M.; et al. Receptor for complement peptide C3a: A therapeutic target for neonatal hypoxic-ischemic brain injury. FASEB J. 2013, 27, 3797-3804. [CrossRef]

110. Hagberg, H.; David Edwards, A.; Groenendaal, F. Perinatal brain damage: The term infant. Neurobiol. Dis. 2016, 92, 102-112. [CrossRef]

111. Moran, J.; Stokowska, A.; Walker, F.R.; Mallard, C.; Hagberg, H.; Pekna, M. Intranasal C3a treatment ameliorates cognitive impairment in a mouse model of neonatal hypoxic-ischemic brain injury. Exp. Neurol. 2017, 290, 74-84. [CrossRef] [PubMed]

112. Brennan, F.H.; Gordon, R.; Lao, H.W.; Biggins, P.J.; Taylor, S.M.; Franklin, R.J.; Woodruff, T.M.; Ruitenberg, M.J. The Complement Receptor C5aR Controls Acute Inflammation and Astrogliosis following Spinal Cord Injury. J. Neurosci. 2015, 35, 6517-6531. [CrossRef]

113. Biggins, P.J.C.; Brennan, F.H.; Taylor, S.M.; Woodruff, T.M.; Ruitenberg, M.J. The Alternative Receptor for Complement Component 5a, C5aR2, Conveys Neuroprotection in Traumatic Spinal Cord Injury. J. Neurotrauma 2017, 34, 2075-2085. [CrossRef]

114. Bialas, A.R.; Stevens, B. TGF- $\beta$ signaling regulates neuronal C1q expression and developmental synaptic refinement. Nat. Neurosci. 2013, 16, 1773-1782. [CrossRef] [PubMed]

115. Shi, Q.; Chowdhury, S.; Ma, R.; Le, K.X.; Hong, S.; Caldarone, B.J.; Stevens, B.; Lemere, C.A. Complement C3 deficiency protects against neurodegeneration in aged plaque-rich APP/PS1 mice. Sci. Transl. Med. 2017, 9. [CrossRef] [PubMed]

116. Chen, T.; Lennon, V.A.; Liu, Y.U.; Bosco, D.B.; Li, Y.; Yi, M.H.; Zhu, J.; Wei, S.; Wu, L.J. Astrocyte-microglia interaction drives evolving neuromyelitis optica lesion. J. Clin. Investig. 2020, 130, 4025-4038. [CrossRef] [PubMed] 
117. Harder, J.M.; Braine, C.E.; Williams, P.A.; Zhu, X.; MacNicoll, K.H.; Sousa, G.L.; Buchanan, R.A.; Smith, R.S.; Libby, R.T.; Howell, G.R.; et al. Early immune responses are independent of RGC dysfunction in glaucoma with complement component C3 being protective. Proc. Natl. Acad. Sci. USA 2017, 114, E3839-E3848. [CrossRef] [PubMed]

118. Howell, G.R.; Macalinao, D.G.; Sousa, G.L.; Walden, M.; Soto, I.; Kneeland, S.C.; Barbay, J.M.; King, B.L.; Marchant, J.K.; Hibbs, M.; et al. Molecular clustering identifies complement and endothelin induction as early events in a mouse model of glaucoma. $J$. Clin. Investig. 2011, 121, 1429-1444. [CrossRef]

119. Pekny, M.; Lane, E.B. Intermediate filaments and stress. Exp. Cell Res. 2007, 313, 2244-2254. [CrossRef]

120. Kim, J.H.; Afridi, R.; Han, J.; Jung, H.G.; Kim, S.C.; Hwang, E.M.; Shim, H.S.; Ryu, H.; Choe, Y.; Hoe, H.S.; et al. Gamma subunit of complement component 8 is a neuroinflammation inhibitor. Brain 2021, 144, 528-552. [CrossRef]

121. Haga, S.; Aizawa, T.; Ishii, T.; Ikeda, K. Complement gene expression in mouse microglia and astrocytes in culture: Comparisons with mouse peritoneal macrophages. Neurosci. Lett. 1996, 216, 191-194. [CrossRef]

122. Lévi-Strauss, M.; Mallat, M. Primary cultures of murine astrocytes produce $C 3$ and factor B, two components of the alternative pathway of complement activation. J. Immunol. 1987, 139, 2361-2366. [PubMed] 